\title{
Determination of iodine content in Fijian foods using spectrophotometric kinetic method
}

\author{
Ajenesh Chandra, Matakite Maata, Surendra Prasad* \\ School of Biological and Chemical Sciences, Faculty of Science, Technology and Environment, The University of the South Pacific, Private Mail Bag, Suva, Fiji
}

A R T I C L E I N F O

\section{Keywords:}

Iodine

Spectrophotometric kinetic method

Foods

Fruits

Vegetables

Seaweeds

\begin{abstract}
A B S T R A C T
The spectrophotometric kinetic method was validated for the determination of iodine in different food samples. The method is based on the iodide catalysed reduction of $\mathrm{Ce}^{4+}$ to $\mathrm{Ce}^{3+}$ by $\mathrm{As}^{3+}$. The absorbance of the kinetic indicator reaction was measured at $370 \mathrm{~nm}$ for exactly $1 \mathrm{~min}$ at $37^{\circ} \mathrm{C}$. The change in absorbance per min, as a measure of initial rate, was plotted against the different iodine concentrations to achieve a linear calibration equation with the $\mathrm{R}^{2}$ value of 0.9998 which showed excellent reproducibility. The limit of detection (LOD) was $1.54 \mathrm{ng} / \mathrm{mL}$ and the limit of quantification (LOQ) was $4.90 \mathrm{ng} / \mathrm{mL}$. The incineration of the food organic matter was achieved by ashing the food samples at $600{ }^{\circ} \mathrm{C}$ using $\mathrm{KOH}$ and $\mathrm{ZnSO}_{4}$ in steps for $3 \mathrm{~h}$. Trace levels of iodine (ng) were determined successfully using the validated spectrophotometric kinetic method for the 9 food samples (36 sub-samples). The Fiji seaweeds, lumiwawa (brown seaweed) showed the highest iodine content being $6373.30 \pm 0.39 \mathrm{ng} / \mathrm{g}$ followed by sea grapes (green seaweed) $1162.81 \pm 0.61 \mathrm{ng} / \mathrm{g}$, lettuce $114.81 \pm 0.08 \mathrm{ng} / \mathrm{g}$, English cabbage $108.40 \pm 0.06 \mathrm{ng} / \mathrm{g}$, Chinese cabbage $104.01 \pm 0.06 \mathrm{ng} / \mathrm{g}$, pumpkin $101.24 \pm 0.08 \mathrm{ng} / \mathrm{g}$, long bean $97.61 \pm 0.10 \mathrm{ng} / \mathrm{g}$, banana $76.18 \pm 0.10 \mathrm{ng} / \mathrm{g}$ and tomato $40.32 \pm 0.04 \mathrm{ng} /$ g. The coefficient of variation for the sample analysis was $<5.31 \%$ with a mean and standard deviation of $2.55 \pm 0.17 \%$ for the food samples analysed. The recovery analysis of iodine from standard samples ranged from $99.84 \pm 0.91 \%$ to $100.24 \pm 5.92 \%$ with an excellent average recovery of $100.06 \pm 3.16 \%$. The analytical coefficient of variation was calculated to be $0.34 \%$ for the food samples analysed. This shows exceptional system analytical stability of the method used in this study.
\end{abstract}

\section{Introduction}

Iodine is an essential trace element and of much interest in nutritional research. In the human body, it is essential for the production of triiodothyronine $\left(\mathrm{T}_{3}\right)$ and thyroxine $\left(\mathrm{T}_{4}\right)$ hormones which are responsible to regulate body temperature and metabolic rate in adults and children and thus for the proper functioning and the development of the human body [1]. Iodine also helps in the maturation of the central nervous system, and the development of foetal and early postnatal life [2]. The most known adverse effect of iodine deficiency is goitre. Goitre is however just one effect of iodine deficiency, the others include endemic cretinism, infant mortality, infertility, miscarriage, mental retardation, neuromuscular defects, and dwarfism. All these are commonly known as Iodine Deficiency Disorders (IDDs) [3]. It is therefore particularly important that pregnant women, breast feeding mothers and young children have an adequate dietary iodine intake [4]. Therefore, the International Council for Control of Iodine Deficiency Disorders (ICCIDD), United Nations Children's Fund (UNICEF) and
World Health Organisation (WHO) recommended that the daily intake of iodine should be $90 \mu \mathrm{g}$ for preschool children ( 0 to 59 months), $120 \mu \mathrm{g}$ for school children ( 6 to 12 years), $150 \mu \mathrm{g}$ for adolescents (above 12 years) and adults, $250 \mu$ f for pregnant and lactating women [5-7].

People get their iodine intake from iodised salt, however this does not always fulfil the requirements for recommended iodine intake levels. The natural dietary sources of iodine in foods include; milk, cereals, fruits, vegetables, eggs, meat, spinach and sea foods. These natural sources may not satisfy the requirements of iodine intake in humans as these iodine sources may not be bioavailable in a form as needed by the human body and also that the iodine concentrations are low [8]. As most iodine enters the human body through food intake so the knowledge of iodine contents in different foods and natural products is essential to estimate the daily iodine intake [4,9]. However, difficulties in the extraction and quantification explain why literature data on the iodine levels in foods are quite limited [10]. Therefore, various analytical methods have been used for the determination of trace amounts of iodine in different types of samples. These include inductively coupled

\footnotetext{
* Corresponding author.

E-mail address: prasad_su@usp.ac.fj (S. Prasad).
} 
plasma mass spectrometry (ICP-MS) [2,3,11-15], radiochemical neutron activation analysis (RNAA) [9,16], ion chromatography (IC) [17-21], high performance liquid chromatography (HPLC) [22], HPLC with UV detection [4], HPLC-diode array detection [23], inductively coupled plasma-atomic emission spectrophotometry (ICP-AES) [24] and atomic absorption spectrophotometry (AAS) [25]. Most of the techniques mentioned above, except RNAA, are not selective, suffer from interferences and need pre-concentration or separation procedures which lead to the loss of iodine [1]. In addition, all these methods require expensive instrumentation and complex sample preparation. Another reason is that iodine concentrations in food matrices are low and losses due to its high volatility make it challenging to analyse [11]. Thus, the majority of methods use the initial step for the determination of iodine in biological materials. This requires the conversion of iodine into iodide or iodate which may be reliably analysed. The conversions are mostly carried out either in dry alkaline medium in a muffle furnace at $600{ }^{\circ} \mathrm{C}$ or wet ashing involving digestion using a strong acid medium. Reproducible results have been obtained only when the losses of iodine are avoided at the incineration stage [26].

Being inexpensive, spectrophotometric kinetic methods to determine iodine content in food and dairy products has continuously been used [10,15,27-29]. Kinetic spectrophotometric procedures have also been utilized to determine the analytes such as drugs in different matrices which highlight the importance of kinetic spectrophotometry [30-32]. It is an attractive procedure because of its high sensitivity and accuracy without using expensive equipment [6]. Sometimes, the insufficient accuracy of the analytical methods used for iodine analysis contribute to the problem [26]. Since food is being the major contributor of the total iodine exposure for humans, ascertaining the iodine nutritional status of Fiji foods and dairy products is of great importance as part of the public health programs. Therefore, the present paper reports the validation of an inexpensive spectrophotometric kinetic method and the determination of iodine content in selected Fiji foods.

\section{Method}

\subsection{Chemicals and reagents}

All chemicals used were of high purity meeting the American Chemical Society (ACS) reagents requirements except arsenic trioxide $\left(\mathrm{As}_{2} \mathrm{O}_{3}\right)$, potassium hydroxide $(\mathrm{KOH})$ and zinc sulphate $\left(\mathrm{ZnSO}_{4}\right)$ which were analytical reagents (AR) purchased from Sigma-Aldrich, Australia. Thus, the ACS reagents potassium iodide (KI, $\geq 99.0 \%$ ), diammonium ceric nitrate $\left(\left(\mathrm{NH}_{4}\right)_{2} \mathrm{Ce}\left(\mathrm{NO}_{3}\right)_{6}, \geq 98.5 \%\right)$, nitric acid $\left(\mathrm{HNO}_{3}, 70 \%\right)$, hydrochloric acid ( $\mathrm{HCl}, \geq 37 \%)$, sulphuric acid $\left(\mathrm{H}_{2} \mathrm{SO}_{4}, 95-98 \%\right), \mathrm{KOH}$ (AR grade), $\mathrm{As}_{2} \mathrm{O}_{3}(\geq 99.0 \%)$ and $\mathrm{ZnSO}_{4}$ (AR grade) were used in this study. The Standard Reference Material Iodised Table Salt (SRM No. 3530) was purchased from the National Institute of Standards and Technology (NIST), USA.

Iodine stock standard was prepared by dissolving $130.8 \mathrm{mg} \mathrm{KI}$ in $1 \mathrm{~L}$ Milli-Q-water (MQW). Iodine working standards (in the range of $2.5-25 \mathrm{ng} / \mathrm{mL}$ ) were prepared by diluting its stock solution. $\mathrm{H}_{2} \mathrm{SO}_{4}$ and $\mathrm{HCl}$ combined reagent was prepared by adding $19.6 \mathrm{~mL}$ concentrated $\mathrm{H}_{2} \mathrm{SO}_{4}$ to $500 \mathrm{~mL}$ water, mixed well and cooled to room temperature. Then $5.4 \mathrm{~mL}$ concentrated $\mathrm{HCl}$ was added, mixed and diluted to $1 \mathrm{~L}$ with MQW. $\mathrm{Ce}^{4+}$ solution $(0.05 \mathrm{M})$ was prepared from $\left(\mathrm{NH}_{4}\right)_{2} \mathrm{Ce}\left(\mathrm{NO}_{3}\right)_{6}$ by dissolving $0.274 \mathrm{~g}$ in $10 \mathrm{~mL}$ MQW. To this, $50 \mathrm{~mL}$ concentrated $\mathrm{HNO}_{3}$ was added followed by addition of $5 \mathrm{~mL} \mathrm{H}_{2} \mathrm{SO}_{4}$. The solution was allowed to cool to room temperature and made up to $100 \mathrm{~mL}$ with MQW. $0.030 \mathrm{M} \mathrm{As}^{3+}$ solution was prepared by dissolving $0.593 \mathrm{~g} \mathrm{As}_{2} \mathrm{O}_{3}$ and $0.6 \mathrm{~g} \mathrm{KOH}$ in $100 \mathrm{~mL} \mathrm{MQW} \mathrm{at} 50^{\circ} \mathrm{C}$. $6 \mathrm{M} \mathrm{KOH}$ solution was prepared by dissolving $168.33 \mathrm{~g} \mathrm{KOH}$ in $500 \mathrm{~mL} \mathrm{MQW.} 0.52 \mathrm{M} \mathrm{ZnSO}_{4}$ solution was also prepared by dissolving $74.76 \mathrm{~g} \mathrm{ZnSO}_{4}$ in $500 \mathrm{~mL} \mathrm{MQW}$.

\subsection{Instrumentation}

An oven with an automatic temperature control was used to maintain the temperature at $120 \pm 0.1^{\circ} \mathrm{C}$. A high temperature Muffle furnace with a programmable temperature setup (Model: YC-1400S) was used for ashing of samples at $600{ }^{\circ} \mathrm{C}$. Perkin Elmer Lambda 365 UV visible spectrophotometer equipped with $10 \mathrm{~mm}$ quartz cells with a thermostatic water bath (Thermoline, Australia) was used. The absorbance for the reduction of $\mathrm{Ce}^{4+}$ in the presence of $\mathrm{As}^{3+}$ at fixed time of $1 \mathrm{~min}$ was measured at $370 \mathrm{~nm}$.

\subsection{Food samples and sampling}

The foods namely: leafy [(lettuce (Lactuca sativa), English cabbage (Brassica oleracea), Chinese cabbage (Brassica chinensis)], fruit [(tomato (Solanum lycopersicum), banana (Musa), long green bean (Vigna unguiculata ssp. sesquipedalis) and pumpkin (Cucurbita moschata)] and sea grapes/green seaweeds (Caulerpalentillifera) and lumiwawa/brown seaweeds (Gracilaria maramae) were analysed for their iodine contents. The samples were purchased randomly from the Suva Municipal market and supermarkets. For each food item, 4 samples of different brands or varieties from 4 different vendors were purchased. Thus, a total of 9 food samples consisting 36 sub-samples were analysed on a fresh weight basis.

Fresh food samples were collected into clean polythene bags and kept in an ice box. The samples were immediately transported to the laboratory. The edible part of each sample was individually taken out and pulverized to obtain particles of required size. The samples which could not be analysed on the same day were kept at $-10^{\circ} \mathrm{C}$ in clean acid washed screw capped plastic bottles until analysis.

\subsection{Ashing procedure and extraction}

The alkaline ashing procedure reported by Mahesh et al. [10] as well as Nitschke and Stengel [4] was modified and used for the determination of iodine in food samples. The fresh food samples $(1 \mathrm{~g})$ were taken in clean dry test tubes in duplicate. For recovery studies, standard solutions containing 4,12 and $18 \mathrm{ng} / \mathrm{mL}$ iodine were analyzed. To the food samples test tubes, $500 \mu \mathrm{L}$ of $6 \mathrm{M} \mathrm{KOH}$ was added and mixed well. The test tubes containing samples were then placed in an oven at $120 \pm 0.1{ }^{\circ} \mathrm{C}$ and the contents were allowed to dry completely for $24 \mathrm{~h}$. The test tubes containing the samples were then transferred to the Muffle furnace, which was operating at $120^{\circ} \mathrm{C}$ for $30 \mathrm{~min}$. The temperature of the Muffle furnace was gradually increased to $600{ }^{\circ} \mathrm{C}$ over $30 \mathrm{~min}$ and incineration was continued for exactly $1 \mathrm{~h}$.

Air was renewed in the Muffle furnace chamber every $15 \mathrm{~min}$ via a timer by opening the furnace door for $10-15 \mathrm{~s}$. After $1 \mathrm{~h}$ the test tubes with incinerated samples were transferred to a desiccator and allowed to cool. Then $500 \mu \mathrm{L}$ of $0.52 \mathrm{M} \mathrm{ZnSO}_{4}$ was added to the samples in the test tubes and the contents dried at $120^{\circ} \mathrm{C}$ for $3 \mathrm{~h}$. The test tubes with samples were then transferred to the Muffle furnace and another ashing procedure was performed for $2 \mathrm{~h}$ at $600{ }^{\circ} \mathrm{C}$ renewing the air in the chamber every $15 \mathrm{~min}$. The ashed samples which were white powder, free from any carbon, were dissolved in MQW in an ultrasonic bath for $10 \mathrm{~min}$ then the samples were centrifuged at $4500 \mathrm{rpm}$ in centrifuge tubes for $10 \mathrm{~min}$. The supernatant was filtered using a $0.45 \mu \mathrm{m}$ filter and stored at room temperature for analysis of total iodine.

\subsection{Analytical procedure sample analysis}

The kinetic spectrophotometric method using the Sandell-Kolthoff reaction as shown below was used to determine the iodine concentration in food samples.

$2 \mathrm{Ce}^{4+}+2 \mathrm{I}^{-} \rightarrow 2 \mathrm{Ce}^{3+}+\mathrm{I}_{2}$ 


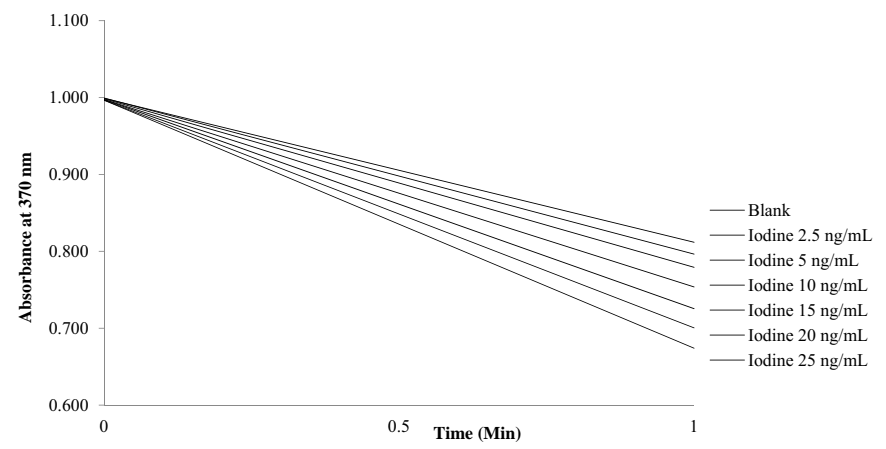

Fig. 1. Plot of average absorbance at $370 \mathrm{~nm}$ for the reduction of $\mathrm{Ce}^{4+}$ by $\mathrm{As}^{3+}$ against time in the presence of different iodine concentrations of $0,2.5,5,10$, 15,20 and $25 \mathrm{ng} / \mathrm{mL}$ at analysis time of $1 \mathrm{~min}$ at $37^{\circ} \mathrm{C}$.

$\mathrm{As}^{3+}+\mathrm{I}_{2} \rightarrow \mathrm{As}^{5+}+2 \mathrm{I}^{-}$

The method was based on the catalytic effect of iodide on $\mathrm{Ce}^{4+}-\mathrm{As}^{3+}$ redox reaction. To initiate the indicator reaction, $0.25 \mathrm{~mL}$ MQW, $0.25 \mathrm{~mL}$ of $\mathrm{H}_{2} \mathrm{SO}_{4}-\mathrm{HCl}$ mixture, $0.25 \mathrm{~mL} \mathrm{Ce}^{4+}$ and $0.25 \mathrm{~mL} \mathrm{As}^{3+}$ reagents were taken in sequence in a $10 \mathrm{~mm}$ path length cuvette. The contents of the cuvette were mixed for $10 \mathrm{~s}$ and pre-incubated at $37^{\circ} \mathrm{C}$ for $2 \mathrm{~min}$. The $0.25 \mathrm{~mL}$ catalyst iodide was added in blank/standard/ sample to initiate the reaction. The decrease in the absorbance as a measure of iodine content i.e. the rate of disappearance of the yellow colour due to the reduction of $\mathrm{Ce}^{4+}$ to $\mathrm{Ce}^{3+}$ at different iodine concentrations ( 0 to $0.25 \mathrm{ng} / \mathrm{mL}$ ) was monitored for $1 \mathrm{~min}$ at $370 \mathrm{~nm}$ [10] as shown in Fig. 1.

The initial rate of the indicator reaction i.e. $\Delta \mathrm{A} / \mathrm{min}$ was calculated from the time-absorbance (A) curves obtained for different iodine concentrations. Each standard was analysed 7 times and the average change in absorbance per minute was calculated and used for the calibration curve as shown in Fig. 2.

Then the iodine content of the samples was calculated using the following formula where $\Delta \mathrm{A}_{\mathrm{s}}$ is the absorbance change for the sample, $\Delta \mathrm{A}_{\mathrm{b}}$ is the absorbance change for the blank, $\mathrm{m}$ is the slope of calibration curve and $\mathrm{d}$ is the sample dilution $(\mathrm{mL})$.

$\frac{\Delta \mathrm{A}_{\mathrm{s}}-\Delta \mathrm{A}_{\mathrm{b}}}{\mathrm{m}} \times 4 \times \mathrm{d}=$ iodine $(\mathrm{ng} / \mathrm{g})$

\section{Results and discussion}

\subsection{Food samples ashing and analysis}

Incineration of organic matter (OM) is generally based on acid or alkaline digestion. Acid digestion methods, as discussed in the literature, are generally effective in the destruction of OM but are not recommended for routine analytical purposes due to the fact that they require large amounts of concentrated acids for each sample $[3,4,11-13,29,33-36]$. Thus, the use of acid digestion becomes impractical when analysing a large number of samples manually. The use of alkaline dry ashing involving $30 \% \mathrm{~K}_{2} \mathrm{CO}_{3}$ and $10 \% \mathrm{ZnSO}_{4}$ resulted in incomplete ashing and poor recoveries of iodine from plants, biological materials and foodstuffs [10]. Incomplete ashing and poor recoveries were also observed when $\mathrm{KOH}$ was used as an ashing agent. Thus, to overcome all these problems, Mahesh et al. [10] used $0.1 \mathrm{~mL} 6 \mathrm{M} \mathrm{KOH}$ and $0.1 \mathrm{~mL} 0.5 \mathrm{M} \mathrm{ZnSO}_{4}$ and ashing of the samples was carried out in two steps: $1 \mathrm{~h}$ with $\mathrm{KOH}$ and $2 \mathrm{~h}$ with $\mathrm{ZnSO}_{4}$.

In the current study, initially poor recoveries were obtained when the procedure specified by Mahesh et al. [10] was followed and this was attributed to incomplete ashing and the presence of OM. Thus, to overcome this problem, a modified alkaline ashing procedure reported by Nitschke and Stengel [4] was referred to which used $<200 \mathrm{mg}$ of sample, $400 \mu \mathrm{L}$ of $17 \mathrm{M} \mathrm{KOH}$ and dried at $150{ }^{\circ} \mathrm{C}$ for $48 \mathrm{~h}$. This was followed by $4 \mathrm{~h}$ incineration at $600{ }^{\circ} \mathrm{C}$. Finally, to overcome the poor recoveries, all the food samples in the present study were analysed by our developed ashing procedure discussed in Section 2.4. The iodine contents in the studied food samples (Table 1 ) were calculated using the calibration equation shown in Fig. 2.

The summary of the determined iodine contents in 9 food samples of three groups (vegetables, fruits and seaweeds) shown in Table 1 clearly shows that the brown seaweed lumiwawa had the highest iodine content being $6373.30 \pm 0.39 \mathrm{ng} / \mathrm{g}$ followed by sea grapes $1162.81 \pm 0.61 \mathrm{ng} /$ $\mathrm{g}$, lettuce $114.81 \pm 0.08 \mathrm{ng} / \mathrm{g}$, English cabbage $108.40 \pm 0.06 \mathrm{ng} / \mathrm{g}$, Chinese cabbage $104.01 \pm 0.06 \mathrm{ng} / \mathrm{g}$, pumpkin $101.24 \pm 0.08 \mathrm{ng} / \mathrm{g}$, long bean $97.61 \pm 0.10 \mathrm{ng} / \mathrm{g}$, banana $76.18 \pm 0.10 \mathrm{ng} / \mathrm{g}$ and tomato $40.32 \pm 0.04 \mathrm{ng} / \mathrm{g}$. A comparison of iodine contents for all the food samples is shown in Fig. 3. It has also been confirmed by other researchers that brown seaweeds generally have the highest iodine content $[4,12,27,36,37]$. The lowest iodine values were witnessed in fruits and vegetables. Almost similar results have also been reported by previous researchers while slight variation may be due to the food samples of different origins [13,38-41].

Table 1

Mean iodine contents $(n=4)$ in food samples analysed on a fresh weight basis.

\begin{tabular}{|c|c|c|c|}
\hline \multirow[t]{2}{*}{ Fresh samples (Scientific name) } & \multicolumn{3}{|c|}{ Iodine content (ng/g) } \\
\hline & Mean $\pm \mathrm{SD}^{\mathrm{a}}$ & Minimum (Mean $\pm \mathrm{SD}^{\mathrm{a}}$ ) & Maximum (Mean $\left.\pm \mathrm{SD}^{\mathrm{a}}\right)$ \\
\hline \multicolumn{4}{|l|}{ Leafy vegetables } \\
\hline Lettuce (Lactuca sativa) & $114.81 \pm 0.08$ & $40.15 \pm 0.03$ & $178.17 \pm 0.14$ \\
\hline English cabbage (Brassica oleracea) & $108.40 \pm 0.06$ & $56.92 \pm 0.03$ & $145.81 \pm 0.07$ \\
\hline Chinese cabbage (Brassica chinensis) & $104.01 \pm 0.06$ & $44.64 \pm 0.04$ & $132.87 \pm 0.12$ \\
\hline \multicolumn{4}{|l|}{ Fruits } \\
\hline Tomato (Solanum lycopersicum) & $40.32 \pm 0.04$ & $24.17 \pm 0.02$ & $53.62 \pm 0.04$ \\
\hline Banana (Musa) & $76.18 \pm 0.10$ & $21.40 \pm 0.04$ & $183.06 \pm 0.23$ \\
\hline Long bean (Vigna unguiculata ssp. sesquipedalis) & $97.61 \pm 0.10$ & $37.64 \pm 0.04$ & $183.98 \pm 0.19$ \\
\hline Pumpkin (Cucurbita moschata) & $101.24 \pm 0.08$ & $48.87 \pm 0.03$ & $183.58 \pm 0.20$ \\
\hline \multicolumn{4}{|l|}{ Seaweeds } \\
\hline Sea grapes (Caulerpa lentillifera) & $1162.81 \pm 0.61$ & $851.92 \pm 0.34$ & $1525.83 \pm 0.83$ \\
\hline Lumiwawa (Gracilaria maramae) & $6373.30 \pm 0.39$ & $2438.68 \pm 0.10$ & $11,000.00 \pm 0.32$ \\
\hline
\end{tabular}

Confidence level at 95\% with 3 degrees of freedom $(t=3.182)$.

SD - Standard deviation.

a Mean of four samples of each food analysed four times $(n=4)$. 


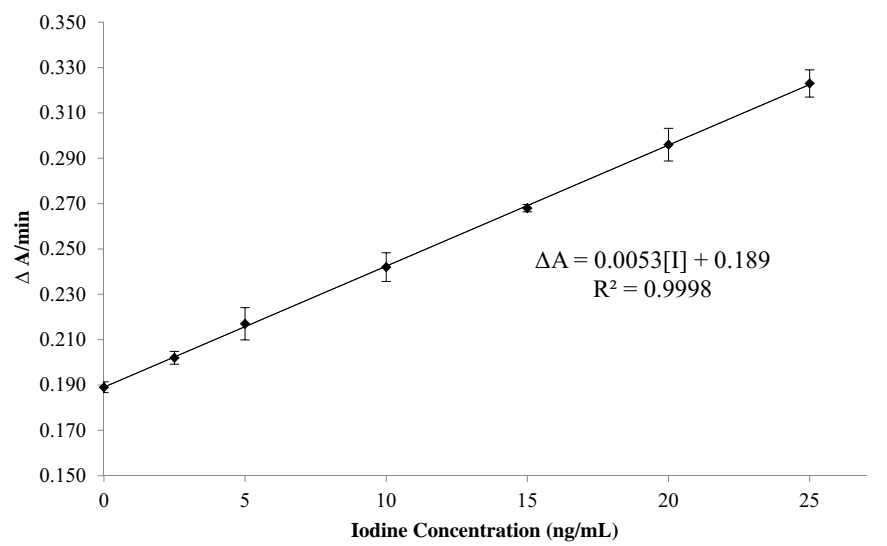

Fig. 2. Calibration curve i.e. plot of change in absorbance per minute $(\Delta \mathrm{A} / \mathrm{min})$ versus iodine concentration.

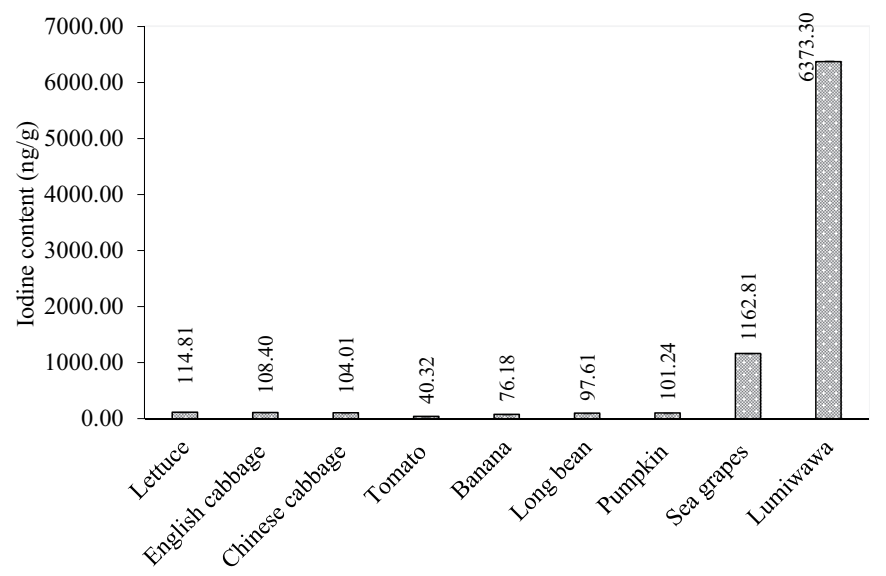

Fig. 3. Graphical representation of determined average iodine contents (ng/g) in the analysed food samples.

\subsection{Precision, limit of detection (LOD) and limit of quantification (LOQ)}

For all the food samples analysed, the coefficient of variation was calculated. It has been reported that a coefficient of variation $<6.0 \%$ with a mean and standard deviation of $3.4 \pm 1.77 \%$ for $>20$ foodstuff analysed on three or more occasions was sufficient to judge the precision. [10]. The coefficient of variation for the food samples analysis in the present study was also $<6.0 \%$ with a mean and standard deviation of $2.55 \pm 0.17 \%$ for the 9 samples analysed each four times. Thus, this method was quite precise. The analytical coefficient of variation in the present study was worked out to be $0.34 \%$ for the 9 food samples analysed which showed exceptional system analytical stability.

The LOD was calculated by multiplying the sample standard deviation by the Student's $t$ value. Thus, for seven replicates and six degrees of freedom, the student's $t$ was taken as 3.143 at $98 \%$ confidence level [39]. The LOD was found to be $1.54 \mathrm{ng} / \mathrm{mL}$. The LOQ was determined following the method reported by Wisconsin Department of Natural Resources Laboratory Certification Program [42] expressed as 10 times the sample standard deviation and calculated to be $4.9 \mathrm{ng} / \mathrm{mL}$.

\subsection{Quality control}

The analyses of known concentrations of 4,12 and $18 \mathrm{ng} / \mathrm{mL}$ iodine were used to monitor the statistical control i.e. for the recovery study. In addition, each food sample was analysed 4 times $(n=4)$ from which the average iodine contents were calculated. The coefficient of variation and the confidence interval were also calculated for each sample to judge the degree of variation. The recovery ranged from 99.84 to $100.24 \%$, as presented in Table 2, represents an excellent quality control.

\subsubsection{Analysis of standard reference materials (SRM)}

The Iodised Table Salt (SRM No. 3530) was analysed to judge the accuracy of the spectrophotometric kinetic method used for iodine determination. The adequacy of applied methodology was verified by usual measures of accuracy, reproducibility and recovery in which $300 \mathrm{mg}$ of the SRM No. 3530 was dissolved in $1 \mathrm{~L}$ of MQW which gave $15.66 \mathrm{ng} / \mathrm{mL}$ iodine concentration. The sample was then placed in an ultrasonic bath for $10 \mathrm{~min}$ for complete dissolution of the salt prior to the spectrophotometric kinetic analysis. The recovery results obtained in terms of $\mathrm{ng} / \mathrm{mL}$ which was further converted to $\mathrm{mg} / \mathrm{kg}$ as reported in NIST SRM No. 3530 certificate are shown in Table 3.

Table 3 also compares the iodine content obtained from the SRM analysis by the present spectrophotometric kinetic method to the certified value of the Iodised Table Salt $(52.2 \pm 4.2 \mathrm{mg} / \mathrm{kg})$ analysed using ICP-MS at NIST, USA. The recovery data shows great accuracy of the present method with excellent recovery of $99.68 \pm 2.38 \%$. Thus, the method applied in the present study was very reliable for the determination of iodine contents in food samples.

\section{Conclusions}

It has been confirmed that trace levels of iodine (ng/g) can be analysed successfully using the modified ashing procedure and the spectrophotometric kinetic method validated. Thus, some commonly consumed Fiji foods were successfully analysed for their iodine content using the spectrophotometric kinetic method. The study confirmed that the seaweed lumiwawa (brown seaweed) had the highest iodine concentration of $6373.30 \pm 0.39 \mathrm{ng} / \mathrm{g}$ among all the food samples studied while sea grapes (green seaweed) had iodine content of $1162.81 \pm 0.61 \mathrm{ng} / \mathrm{g}$. Low iodine contents were shown by the fruit group where tomato showed the lowest iodine content as $40.32 \pm 0.04 \mathrm{ng} / \mathrm{g}$. The data presented give clear indication of the iodine contents of some commonly consumed foods in Fiji and form a basic database on iodine levels from foods in the country. The spectrophotometric kinetic method used has definite advantages of being very sensitive, versatile and can be adapted as an inexpensive method for the determination of iodine in foods.

Table 2

Recovery study from the standard iodine solutions at 4,12 , and $18 \mathrm{ng} / \mathrm{mL}$.

\begin{tabular}{|c|c|c|c|c|}
\hline Iodine concentration $(\mathrm{ng} / \mathrm{mL})$ & Nominal $\pm \mathrm{SD}^{\mathrm{a}}(\mathrm{ng} / \mathrm{mL})$ & Recovery \pm RSD (\%) & Standard analytical error (\%) & Confidence interval $^{\mathrm{b}}$ \\
\hline 4.0 & $4.01 \pm 0.24$ & $100.24 \pm 5.92$ & 0.60 & 0.38 \\
\hline 12.0 & $11.98 \pm 0.11$ & $99.84 \pm 0.91$ & 0.23 & 0.17 \\
\hline 18.0 & $18.02 \pm 0.47$ & $100.10 \pm 2.64$ & 0.88 & 0.76 \\
\hline
\end{tabular}

\footnotetext{
a Mean for four determinations $(n=4)$.

b Confidence level at 95\% with 3 degrees of freedom $(t=3.182)$.
} 
Table 3

Summary of the recovery results obtained from NIST SRM No. 3530 - (Iodised Table Salt) analysis.

\begin{tabular}{|c|c|c|c|c|}
\hline Iodine concentration (ng/mL) & $\begin{array}{l}\text { Iodine found } \pm \mathrm{SD}^{\mathrm{a}} \\
(\mathrm{ng} / \mathrm{mL})\end{array}$ & $\begin{array}{l}\text { SRM certified iodine } \pm \text { SD } \\
(\mathrm{mg} / \mathrm{kg})\end{array}$ & $\begin{array}{l}\text { Iodine found in } \mathrm{SRM} \pm \mathrm{SD}^{\mathrm{a}} \\
(\mathrm{mg} / \mathrm{kg})\end{array}$ & Recovery \pm RSD (\%) \\
\hline 15.66 & $15.61 \pm 0.37$ & $52.2 \pm 4.2$ & $52.03 \pm 0.37$ & $99.68 \pm 2.38$ \\
\hline
\end{tabular}

a Mean for seven determinations $(n=7)$.

\section{Acknowledgements}

The authors are grateful to the Faculty of Science, Technology and Environment, the University of the South Pacific for the award of MSc research grant to Ajenesh Chandra.

\section{References}

[1] P.R. Bhagat, R. Acharya, A.G. Nair, A.K. Pandey, N.S. Rajurkar, A.V. Reddy, Estimation of iodine in food, food products and salt using ENAA, Food Chem. 115 (2009) 706-710.

[2] H. Gónzalez-Iglesias, R.R. de la Flor St Remy, J. López-Sastre, B. FernándezColomer, A. Ibáñez-Fernández, G. Solís, A. Sanz-Medel, M.L. Fernández-Sánchez, Efficiency of iodine supplementation, as potassium iodide, during lactation: a study in neonates and their mothers, Food Chem. 133 (2012) 859-865.

[3] K.M. Eckhoff, A. Maage, Iodine content in fish and other food products from East Africa analyzed by ICP-MS, J. Food Compos. Anal. 10 (1997) 270-282.

[4] U. Nitschke, D.B. Stengel, A new HPLC method for the detection of iodine applied to natural samples of edible seaweeds and commercial seaweed food products, Food Chem. 172 (2015) 326-334.

[5] World Health Organisation (WHO), Assessment of Iodine Deficiency Disorders and Monitoring their Elimination, 3rd edition, WHO Press, Geneva, Switzerland, 2007 Available online at http://www.who.int/iris/handle/10665/43781, Accessed date: 26 November 2016.

[6] C.P. Shelor, P.K. Dasgupta, Review of analytical methods for the quantification of iodine in complex matrices, Anal. Chim. Acta 702 (2011) 16-36.

[7] U.S. Institute of Medicine (IOM), Dietary Reference Intakes for Vitamin a, Vitamin K, Arsenic, Boron, Chromium, Copper, Iodine, Iron, Manganese, Molybdenum, Nickel, Silicon, Vanadium and Zinc, Academy Press, Washington, DC, 2001.

[8] P.S. Kulkarni, S.D. Dhar, S.D. Kulkarni, A rapid assessment method for determi nation of iodate in table salt samples, J. Anal. Sci. Technol. 4 (2013) 1-4.

[9] A. Osterc, V. Stibilj, Investigation of declared values of iodine in food supplements on the Slovene market, Acta Agriculturae Slovenica 87 (2006) 245-253.

[10] D.L. Mahesh, Y.G. Deosthale, B.N. Rao, A sensitive kinetic assay for the determination of iodine in foodstuffs, Food Chem. 43 (1992) 51-56.

[11] A. Leufroy, L. Noël, P. Bouisset, S. Maillard, S. Stéphane, C. Xhaard, F. Vathaire, T. Guérin, Determination of total iodine in French Polynesian foods: method validation and occurrence data, Food Chem. 169 (2015) 134-140.

[12] V. Romarís-Hortas, C. García-Sartal, M.C. Barciela-Alonso, R. Domínguez-González, A. Moreda-Piñeiro, P. Bermejo-Barrera, Bioavailability study using an in-vitro method of iodine and bromine in edible seaweed, Food Chem. 124 (2011) 1747-1752.

[13] M. Haldimann, A.B.A. Alt, K. Blondeau, Iodine content of food groups, J. Food Compos. Anal. 18 (2005) 461-471.

[14] J.V. Dyke, P.K. Dasgupta, A.B. Kirk, Trace iodine quantitation in biological samples by mass spectrometric methods. The optimum internal standard, Talanta 79 (2009) 235-242.

[15] E.S. Pieter, Methods for determination of iodine in urine and salt, Best Pract. Res. Clin. Endocrinol. Metab. 24 (2010) 77-88.

[16] D. Adotey, V. Stibilj, Y. Serfor-Armah, B. Nyarko, A. Osterc, Daily dietary intake of iodine by adolescents in three residential care orphanages in southern Ghana, Afr. J. Food Sci. 5 (2011) 555-567.

[17] B. Rebary, P. Paul, P.K. Ghosh, Determination of iodide and iodate in edible salt by ion chromatography with integrated amperometric detection, Food Chem. 123 (2010) 529-534.

[18] L. Rong, L.W. Lim, T. Takeuchi, Determination of iodide in seawater using C30 column modified with polyoxyethylene oleyl ether in ion chromatography, Talanta 72 (2007) 1625-1629.

[19] T.K. Malongo, S. Patris, P. Macours, F. Cotton, J. Nsangu, J.M. Kauffmann, Highly sensitive determination of iodide by ion chromatography with amperometric detection at a silver-based carbon paste electrode, Talanta 76 (2008) 540-547.

[20] C. Bruggink, W.J. Rossum, E. Spijkerman, E.S. Beelen, Iodide analysis by anionexchange chromatography and pulsed amperometric detection in surface water and adsorbable organic iodide, J. Chromatogr. A 1144 (2007) 170-174.

[21] K.K. Hu, W.X. Huang, Y.H. Su, R.Z. Hu, Simultaneous determination of fluorine and iodine in urine by ion chromatography with electrochemical pretreatment, Chin. Chem. Lett. 20 (2009) 1483-1486.

[22] J. Melichercik, L. Szijarto, A.R. Hill, Comparison of ion-specific electrode and high performance liquid chromatography methods for the determination of iodide in milk, J. Dairy Sci. 89 (2006) 934-937.

[23] M. Gupta, A.K. Pillai, A. Singh, A. Jain, K.K. Verma, Salt-assisted liquid-liquid microextraction for the determination of iodine in table salt by high-performance liquid chromatography-diode array detection, Food Chem. 124 (2011) 1741-1746.

[24] I. Varga, Iodine determination in dietary supplement products by TXRF and ICPAES spectrometry, Microchem. J. 85 (2007) 127-131.

[25] O. Haase, J.A. Broekaert, Development of an on-line procedure for the indirect determination of iodide by flow-injection cold-vapor atomic absorption spectrometry, Spectrochim. Acta B 57 (2002) 157-165.

[26] N. Patzeltová, Determination of microquantities of iodine in biological materials, Chem. Pap. 47 (1993) 237-239.

[27] A. Moreda-Piñeiro, A. Bermejo-Barrera, P. Bermejo-Barrera, Concentrations of iodide and total iodine in edible seaweeds harvested on the Galician coast (Northwest Spain), Bot. Mar. 50 (2007) 65-71.

[28] T. Longvah, Y.G. Deosthale, Iodine content of commonly consumed foods and water from the goitre-endemic northeast region of India, Food Chem. 61 (1998) 327-331.

[29] P. Cressey, Iodine content of New Zealand dairy products, J. Food Compos. Anal. 16 (2003) 25-36.

[30] N. Rahman, H. Rahman, S.M. Haque, Kinetic spectrophotometric method for the determination of perindopril erbumine in pure and commercial dosage forms, Arab. J. Chem. 10 (2017) S831-S838.

[31] N. Rahman, S. Khan, Kinetic modelling for the assay of nortriptyline hydrochloride using potassium permanganate as oxidant, J. Am. Soc. Assoc. Pharm. Sci. 16 (2015) 569-578.

[32] N. Rahman, M. Kashif, Hypothesis testing for the validation of the kinetic spectrophotometric methods for the determination of lansoprazole in bulk and drug formulations via Fe(iii) and Zn(ii) chelates, Drug Test. Anal. 2 (2010) 137-143.

[33] J.D. Acland, The estimation of serum protein-bound iodine by alkaline inceration, Biochemistry 66 (1957) 177-188.

[34] G. Aumont, J.C. Tressol, Rapid method for the direct determination of inorganic iodine in plasma using ion exchange chromatography and the Sandell and Kolthoff reaction, Analyst 112 (1987) 875-878.

[35] G. Aumont, J.C. Tressol, Improved routine method for the determination of total iodine in urine and milk, Analyst 111 (1986) 841-843.

[36] M. Shah, R.G. Wuilloud, S.S. Kannamkumarath, J.A. Caruso, Iodine speciation studies in commercially available seaweed by coupling different chromatographic techniques with UV and ICP-MS detection, J. Anal. At. Spectrom. 20 (2005) $176-182$.

[37] G.L. Diego, B.A. María del Carmen, M.P. Antonio, B.B. Adela, Microwave-assisted alkaline digestion combined with microwave-assisted distillation for the determination of iodide and total iodine in edible seaweed by catalytic spectrophotometry, Anal. Chim. Acta 542 (2005) 287-295.

[38] T. Longvah, G. Toteja, A. Upadhyay, Iodine content in bread, milk and the retention of inherent iodine in commonly used Indian recipes, Food Chem. 136 (2013) 384-388.

[39] Centre for Food Safety-Hong Kong, Risk Assesment Studies-Dietary Iodine Intake in Hong Kong Adults, Risk Assessment Section, Centre for Food Safety, Food and Environmental Hygiene department, Hong Kong, 2011 Available online at http:// www.cfs.gov.hk, Accessed date: 5 January 2017.

[40] R. Wenlock, D. Buss, R. Moxon, N. Bunton, Trace nutrients, iodine in British food, Br. J. Nutr. 47 (1982) 381-390.

[41] J.A.T. Pennington, S.A. Schoen, G.D. Salmon, B. Young, R.D. Johnson, R.W. Marts, Composition of core foods of the U. S. food supply, 1982-1991, J. Food Compos. Anal. 8 (1995) 171-217.

[42] Wisconsin Department of Natural Resources Laboratory Certification Program, Analytical Detection Limit Guidance and Laboratory Guide for Determining Method Detection Limits, Available online at http://www.dnr.state.wi.us, (April 1996), Accessed date: 26 May 2017. 